\title{
Benthic response to a pelagic front
}

\author{
Alf B. Josefson*, Daniel J. Conley \\ National Environmental Research Institute, Dept of Marine Ecology and Microbiology, PO Box 358, DK-4000 Roskilde, Denmark
}

\begin{abstract}
With the aim of studying the influence of pelagic front primary production on the benthic system underneath, biomarkers of benthic organic matter constituents and macrofaunal abundance and biomass were measured on stations in a grid extending through the area of the Skagerrak-Kattegat pelagic plume front. A time persistent pattern of chl a and phaeopigments in the surface sediment was observed, with chl a / chl a + phaeopigments ratios exceeding 0.5 , suggesting high input of phytoplankton to the bottom near the front. Of the sediment variables chl $a$, phaeopigments, particulate organic nitrogen (PON), particulate organic carbon (POC) and biogenic silica (BSi), the pigments showed the highest correlation with benthic biomass and abundance. Chl a and phaeopigments together explained nearly half of the variation in benthic biomass and the non-polychaete fraction of abundance. $\mathrm{C} / \mathrm{N}$ ratio showed the expected negative relationship with biomass but was not statistically significant. PON, BSi and POC were poor indicators of faunal variables. Results suggest that sediment chlorophyll and its breakdown products may be useful biomarkers of labile organic matter. The organic matter $(O M)$ gradient significantly influenced faunal structure. Polychaete and echinoderm AFDW were positively correlated with chl a and with phaeopigments. A major part of the positive faunal response was due to the burrowing ophiuroid Amphiura filiformis and its commensal Mysella bidentata. While the host was best correlated with phaeopigments, the commensal correlated equally well with both chl $a$ and phaeopigments. Faunal changes in composition suggested increased importance of subsurface feeding deep in the sediment in response to increased OM loading. Surface deposit-feeders did not respond to the high levels of labile OM in the middle of the area. Results indicate strong pelagic-benthic coupling near the front and in the area with a mixed water column and are consistent with the hypotheses that pelagic-benthic energy coupling is stronger in mixed areas compared to those which are stratified and that increased OM loading may increase subsurface dwelling and OM processing through benthic burrowing biomass.
\end{abstract}

KEY WORDS: Pelagic-benthic coupling · Biomass · Fronts - Chlorophyll

\section{INTRODUCTION}

An important task in system ecology is to identify and quantify major pathways of energy between different compartments in ecosystems. In the marine environment the coupling between pelagic and benthic systems is an issue subject to growing interest in recent years (Graf 1992). Although it may be a consensus that benthic activity in marine areas is dependent on phytoplankton production in the overlying water column (e.g. Hargrave 1973, Grebmeier \& McRoy 1989), little is still known about the factors and scales involved in coupling between pelagic and benthic productivity. This is in particular true for open sea areas. One source

•E-mail: aj@dmu.dk of heterogeneity in pelagic productivity potentially influencing the benthic system is fronts, that is, areas where water masses with different physico-chemical properties such as salinity, temperature or nutrients come into contact with each other. Previous studies suggest increased chlorophyll concentrations and pelagic primary production in such areas (Pingree et al. 1978, Richardson 1985, Riegman et al. 1990, Heilmann et al. 1994) as well as changes in pelagic community structure (Lindley \& Williams 1994).

In the spatial dimension estuarine frontal systems (plume fronts) may be analogous to the time period encompassing the spring phytoplankton bloom, where temporarily a mixed situation is followed by a stratified situation (Kiørboe 1993). Similar to the spring bloom chlorophyll maxima in fronts often are due to large 
phytoplankters, i.e. diatoms, which show high sinking rates (Smetacek 1985, Kiørboe 1993). Unlike the spring bloom, which is considered to be a major channel between pelagic and benthic productivity (Smetacek 1980, 1985, Graf et al. 1982), frontal blooms are often temporally more persistent. The persistence of diatom blooms together with high primary production per unit time are likely to result in greater inputs of labile organic matter (OM) to the bottom below. Along with the fact that frontal areas often are spatially restricted thereby creating steep gradients of $O M$, this makes frontal areas particularily suitable for studies of changed OM loading on benthic structure and processes. It may be expected that benthic activity, such as secondary production, is enhanced under fronts, but little is known about coupling between fronts and the benthic system underneath (Barry \& Dayton 1991). Some studies in the North Sea (Creutzberg et al. 1984, Creutzberg 1985, Duineveld et al. 1987, Cramer 1990) and the Bering Sea (Iverson et al. 1979) do indicate increased benthic activity in such areas.

In this paper, we address the question of whether or not the presence of a specific pelagic front has consequences for the benthic system underneath. We examined spatial patterns of OM in the sediment and of benthic macrofaunal abundance and biomass, the latter being a good predictor of secondary production (Tumbiolo \& Downing 1994), on transects going through the area of the Skagerrak-Kattegat pelagic front. We have chosen OM constituents with different labilities to distinguish between recent vertical sedimentation events and more refractory OM inputs, which are more related to horizontal redistribution of OM. Specifically, we (1) investigate if the pelagic gradient in chlorophyll was reflected in $O M$ levels in the bottom using different $O M$ biomarkers in the sediment and animal chlorophyll contents, (2) examine possible consequences of front production for benthic standing stock (biomass and abundance), and (3) examine possible consequences for macrobenthic structure, which relates to function. Our null hypotheses were that no systematic patterns of sediment $O M$ and fauna that could be attributed to other factors than water depth and sediment texture were present in the area. To our knowledge, this study is the first attempt to systematically correlate both sediment $O M$ variables and benthic biomass and structure in a frontal area. Our results are also pertinent to the problem of using sedimentary $\mathrm{N}$ and $\mathrm{C}$ bulk measures as predictors of benthic production.

\section{INVESTIGATED AREA}

The Skagerrak-Kattegat is a transition area between the Baltic Sea and the North Sea, and may be viewed as a large estuary, with fresh water input from the Baltic Sea as well as from the surrounding land areas (Fig. 1). The Kattegat is stratified during large parts of the year with a halocline occurring at an average $15 \mathrm{~m}$ depth. At the northern border of the Kattegat, where the low saline (ca 25 PSU on the surface) Baltic water meets higher saline (>33 PSU) water from the North Sea and the Atlantic, a front is formed. On the western side this contact occurs close to Cape Skagen, the northern tip of Denmark (Fig. 1). The exact positions of the front are partly determined by the balance between the currents from the Skagerrak/North Sea and from the Baltic, which are determined by e.g. wind conditions and the magnitude of the fresher Baltic outflow (Richardson 1985, Poulsen 1991). However, during the biologically active period, April-October/ November, this front is a predictable feature and is approximately positioned in the northern Kattegat between $57^{\circ} 20^{\prime}$ and $58^{\circ} 00^{\prime} \mathrm{N}$ latitude (Heilmann et al. 1994, Lindley \& Williams 1994). The mean position of the 29 PSU isohaline, based on data from the entire 20th century (Rodhe 1996), indicates the approximate mean position of the front (Fig. 1). The orientation of the front in this period is generally SW to NE starting off Cape Skagen at approximately $57^{\circ} 45^{\prime} \mathrm{N}$ latitude (Poulsen 1991, Jakobsen et al. 1994, Rodhe 1996). Heilmann et al. (1994, their Fig. 3) showed water column stability estimates (to $30 \mathrm{~m}$ water depth) from 10 $\mathrm{SE}$ to NW oriented transects close to our investigation area. Data were taken in the period March to November in various years in the 1980s and 1990s. During 8 out of 10 cruises, stability was clearly lower north of $57^{\circ} 45^{\prime} \mathrm{N}$ latitude. To the south the water is stratified and to the north the water is more often mixed down to the bottom (down to $>30 \mathrm{~m}$ ). Increased chlorophyll concentrations in the water column have been reported from the area where the front occurs (Heilmann et al. 1994), and in contrast to adjacent areas, the front production in the summer period accounts for a major part of phytoplankton production during the year (Jakobsen et al. 1994). The bottom in the investigation area consists mostly of soft sediments, with a surface water content ranging from 30 to $70 \%$, and the water depth varies between 25 and $150 \mathrm{~m}$ with the greatest depths in the northern part (Fig. 1).

\section{MATERIAL AND METHODS}

Quantitative sediment samples were taken at 35 stations situated on 3 north to south oriented, parallel transects bisecting the area where the SkagerrakKattegat pelagic front is positioned during AprilOctober/November (Fig. 1). Samples for sediment variables, 1 per station, were taken during 3 cruises: in 

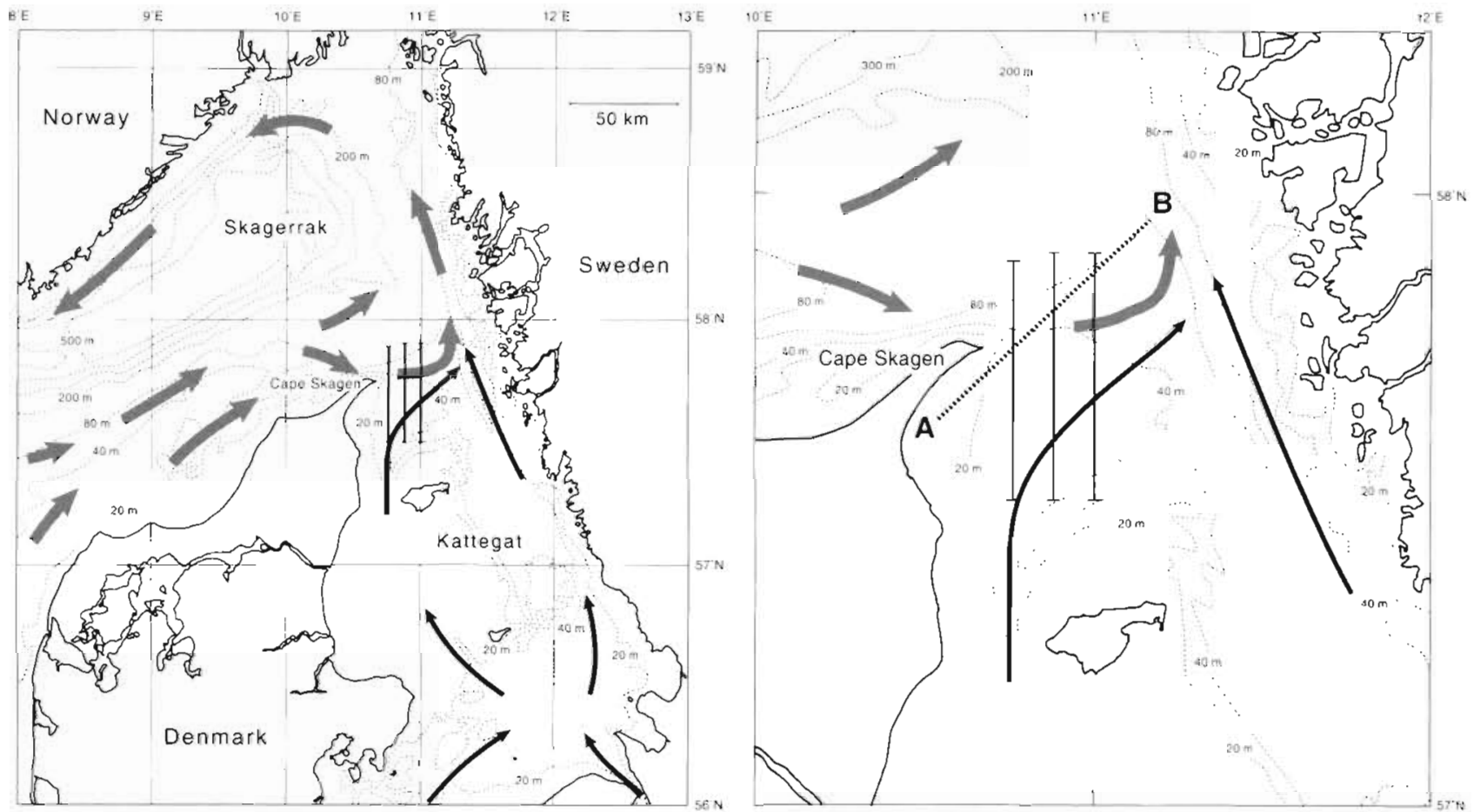

Fig. 1. Investigated area with positions of the 3 benthic transects (vertical solid straight lines), bathymetry, and a simplified picture of surface currents (modified from Svansson 1975). Shaded arrows undicate circulation in the Skagerrak, and solid arrows the Baltic outflow. Line A-B in enlarged figure shows average position of the 29 PSU surface isohaline (Rodhe 1996), indicating the approximate position of the Skagerrak-Kattegat Front in the period May-August

June and October 1993 and in June 1994. In 1993 a Haps-corer $\left(0.0125 \mathrm{~m}^{2}\right)$ was used and in June 1994 a $0.1 \mathrm{~m}^{2}$ USNEL box-corer was used. In June 1994 the macrofauna from the 0 to $20 \mathrm{~cm}$ stratum, retained on a $1 \mathrm{~mm}$ mesh, was collected from the same sample as sediment variables.

Macrofaunal samples were immediately deep frozen. In the laboratory the samples were sorted and identified at least to the major taxa Polychaeta, Mollusca, Echinodermata and Crustacea. Individuals of the 3 latter groups were counted and in most cases identified to species. Ash free dry weight (AFDW) was determined after drying to constant weight at 60 to $80^{\circ} \mathrm{C}$ and ashing in a muffle furnace at $500^{\circ} \mathrm{C}$ for at least $4 \mathrm{~h}$.

Sediment variables were determined from 3 syringe sized (30 $\mathrm{mm}$ diameter) sub-samples of the 0 to $1 \mathrm{~cm}$ stratum which were pooled and deep frozen (below $-20^{\circ} \mathrm{C}$ ) until analyzed. Particulate organic carbon and nitrogen ( $\mathrm{POC}$ and $\mathrm{PON}$ ) were determined in June 1994 on dried samples corrected for carbonate C (separated by ignition). Measurements were made on a Perkin-Elmer elemental analyzer model 240C. The plant pigments, chlorophyll a (chl a) and phaeopigments were determined spectrophotometrically with the acid method (Lorenzen 1967). Extraction of thawed samples were made in the dark for $6 \mathrm{~h}$ in $96 \%$ ethanol. Lorenzen (1967) used acetone as extraction fluid, but Jespersen \& Christoffersen (1987) found complete extraction of chl a from phytoplankton samples after $6 \mathrm{~h}$ in $96 \%$ ethanol. The constant, determined by the absorption coefficient for chl $a$ in ethanol $\left(83.4 \mathrm{l} \mathrm{g}^{-1}\right.$ $\mathrm{cm}^{-1}$ ) and the acid factor (1.7), used in Lorenzen's formula was 29.1. Spectrophotometric determination with the acid method is likely to give less accurate estimates of chl a compared to HPLC-methods (e.g. Mantoura \& Llewellyn 1983). This is probably in particular true for sediment samples where chlorophyll breakdown products are abundant. Consequently chl a is likely to be overestimated in our samples. Daemen (1986) reported an overestimation of 3 to $20 \%$ from Dutch sediments. However, since we only are interested in relative estimates, and we have used the same method for all samples, we do not consider this inaccurracy as a problem for our conclusions.

Water content and dry weight were estimated on one-half of the sample. Since sediment dry matter varies between stations (Fig. 2), the sediment variables are expressed per volume wet sediment using the water content and a sediment specific density of 2.5 . Biogenic silica (BSi) was used as an indicator of diatoms. BSi is a chemical estimate of siliceous micro- 
fossil abundance in the sediments (Conley 1988). BSi was measured using a wet alkaline extraction (DeMaster 1981). Briefly, ca $30 \mathrm{mg}$ of dry sediment was leached in $1 \% \mathrm{Na}_{2} \mathrm{CO}_{3}$ for a period of $5 \mathrm{~h}$ at $85^{\circ} \mathrm{C}$. Aliquots were withdrawn at 3,4 , and $5 \mathrm{~h}$ and analyzed for dissolved silicate (DSi). The amount of BSi was estimated from the intercept of the line of the time course extraction (DeMaster 1981). Water content was used as a measure of sediment texture.

From each macrofaunal sample 10 individuals of the ophiuroid Amphiura filiformis were placed in ethanol for extraction of plant pigments. Estimations of the chl $a$ and phaeopigment content were made using the same methods as for the sediment. The content of chlorophyll and chlorophyll breakdown products was expressed per 9 AFDW which was obtained by measuring the oral width on the extracted individuals and using the relationship between oral width and AFDW given in Josefson \& Jensen (1992). It should be noted, however, that the correct value of the constant $a$ in the size-AFDW relation given therein is 0.000928 . The calculated weights of these individuals were added to weights of remaining macrofauna.

Spearman's rank correlation analysis, least square linear regression analyses, and the nonlinear regression LOWESS (Cleveland 1979) were used to infer relationships between variables. The statistical package SYSTAT (Systat Inc.) was used for all calculations.

\section{RESULTS}

\section{Sediment variables}

Chl a and phaeopigments measured in June 1993 and 1994 and in October 1993 showed clear spatial patterns with high values mostly in the northern part of the area (Fig. 2). Peak values occur from $57^{\circ} 45^{\prime} \mathrm{N}$ latitude northward and, at least for chl a from the 2 June cruises, there is a tendency toward a SW to NE orientation of the high values (Fig. 2). In October 1993 the highest values on the middle and eastern transects occurred more to the south compared to the June data. Chl a and phaeopigment concentrations varied mostly by a factor of 3 or 4 within the area. Correlation analysis between individual chl $a$ and phaeopigments on the 3 occasions showed mostly positive correlations between the dates, and the sum of chl a and phaeopigments showed highly significant positive correlations between all dates $(\mathrm{p}<0.01)$ (Table 1$)$. These results suggest some temporal persistence of the pigment pattern. The $2 \mathrm{chl}$ a June data sets showed the highest correlation, and concentrations were higher in June than in October. Concentrations of chl $a$ and phaeopigments were clearly higher in the northern half of the area (north of $57^{\circ} 45^{\prime} \mathrm{N}$ latitude). In this area the relative amount of phaeopigments increased with water depth, indicated by a significant negative correlation between the mean chl a / chl $a+$ phaeopigments ratio for all 3 dates and water depth $(p<0.01, n=13$, Spearman's $r=-0.687$ ).

The ratio between chl $a$ and chl $a+$ phaeopigments from all 3 cruises showed a unimodal pattern along the 3 transects with highest values mid-way along the transects (Fig. 3). The ratios varied generally between 0.15 and 0.60 , suggesting that chl a constituted up to more than half of these sediment pigments.

Results of correlation analysis between sediment OM variables, biogenic silica, water content of the sediment and water depth are shown in Table 2. High positive correlations occurred between chl $a$ and phaeopigments, between PON, POC and water content, and between phaeopigments and depth. Significant negative correlations occurred between chl $a$ and $\mathrm{C} / \mathrm{N}$ ratio, and between PON and depth. BSi was not significantly correlated with any other variable, but showed positive Spearman's $r$ with all OM measures, the highest one with POC (Table 2).

Table 1. Correlation matrix using Spearman's $r$ between sediment pigments from 3 different sampling dates: June 1993 (J3), October $1993(\mathrm{O} 3)$ and June $1994(\mathrm{~J} 4) . \mathrm{CP}=\mathrm{Chl} a+$ phaeopigments, $\mathrm{Chl} a=\mathrm{chl} \mathrm{a}_{1}$ Phae $=$ phaeopigments. ${ }^{*} \mathrm{r}_{0.05}=0.335, \cdot \mathrm{r}_{001}=$ $0.430, \mathrm{n}=33$

\begin{tabular}{|c|c|c|c|c|c|c|c|c|c|}
\hline & CP J3 & $\mathrm{CPO} 3$ & CP J4 & Chl a J3 & Chl a $\mathrm{O} 3$ & Chl a J4 & Phae J3 & Phae $\mathrm{O} 3$ & Phae J4 \\
\hline CP J3 & 1.000 & $0.549^{\cdots}$ & $0.606 \cdots$ & - & - & - & - & - & - \\
\hline СP O3 & & 1.000 & $0.598^{*}$ & - & - & - & - & - & - \\
\hline CP J4 & & & 1.000 & - & - & - & - & - & - \\
\hline Chl a J3 & & & & 1.000 & $0.354^{\circ}$ & $0.600^{\cdots}$ & $0.484^{\cdots}$ & $0.367^{\circ}$ & 0.338 \\
\hline Chl a O3 & & & & & 1.000 & 0.213 & 0.304 & -0.086 & -0.169 \\
\hline Chl a J4 & & & & & & 1.000 & $0.437^{\circ}$ & $0.426^{\circ}$ & $0.648^{\cdots}$ \\
\hline Phae J3 & & & & & & & 1.000 & 0.284 & $0.470 \%$ \\
\hline Phae 03 & & & & & & & & 1.000 & $0.635^{\circ}$ \\
\hline Phae J4 & & & & & & & & & 1.000 \\
\hline
\end{tabular}



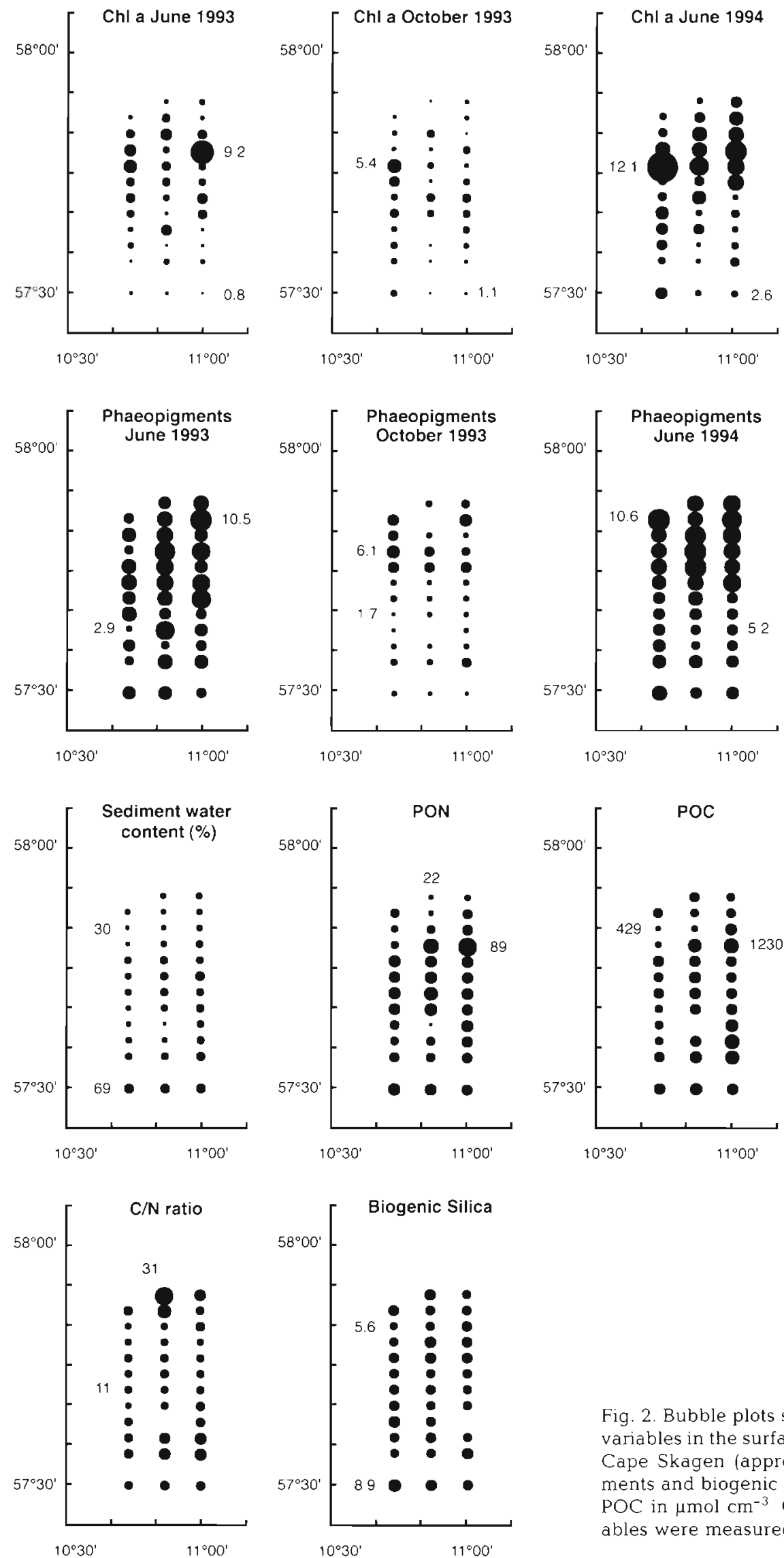

Fig. 2. Bubble plots showing spatial distributions of sediment variables in the surface sediment along 3 benthic transects off Cape Skagen (approx. 57 $45^{\prime} \mathrm{N}$ latitude). Chl a, phaeopigments and biogenic silica are given in $\mu \mathrm{g} \mathrm{cm}^{-3}$ and PON and

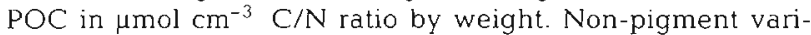
ables were measured in June 1994. High and low values are given for scale 

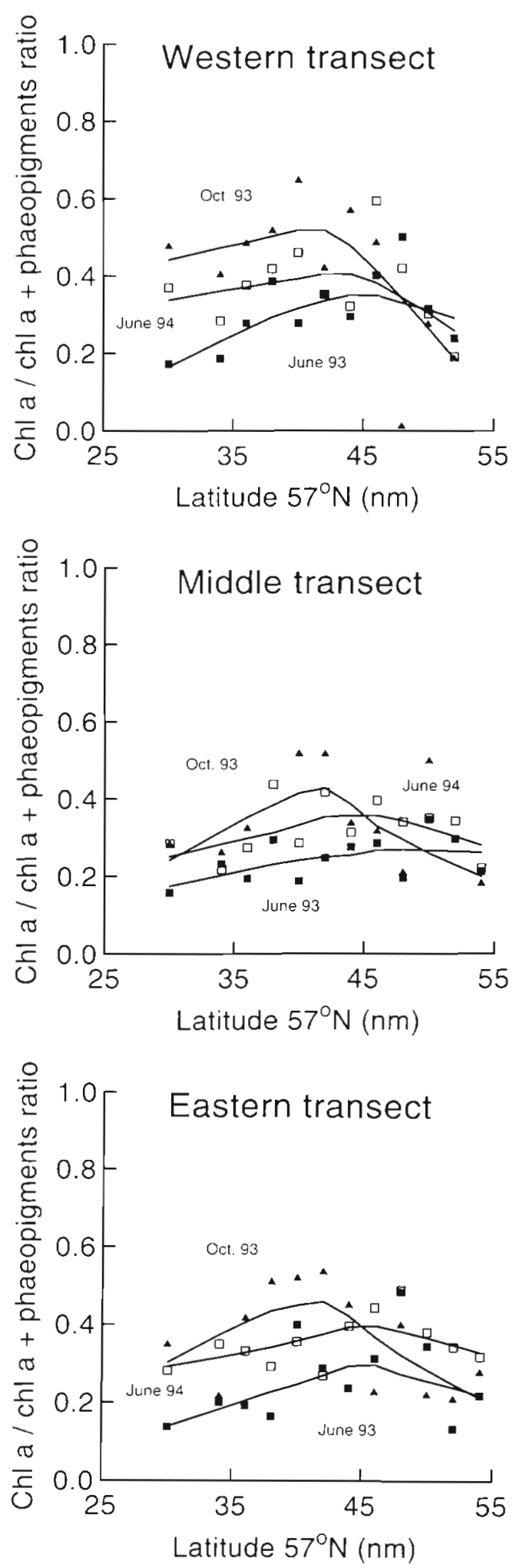

Fig. 3 Distributions with latitude of sediment chl a / chl $a+$ phaeopigments ratios from June 1993 (ロ), October 1993 (4) and June $1994(\square)$, analysed with LOWESS nonlinear smoothing (tension factor $=0.75$ )

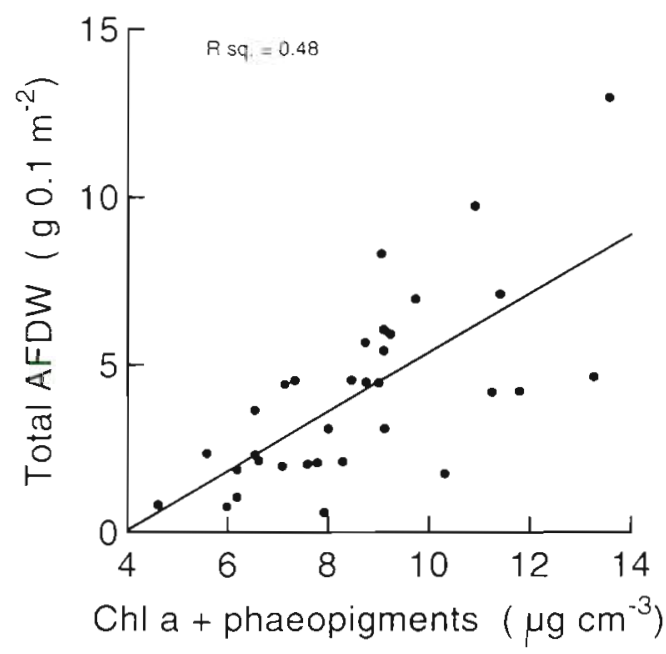

Fig. 4 Total macrobenthic biomass plotted against chl a+ phaeopigments (average for 1993 and 1994) in the sediment analysed with linear regression

\section{Macrofaunal abundance and biomass}

Total biomass (AFDW) was significantly positively correlated with chl $a+$ phaeopigments $(p<0.01)$, phaeopigments $(p<0.01)$, chl a $(p<0.05)$ and depth $(p<$ 0.01 ), but was not correlated with remaining sediment variables (Table 3). Linear regression between total biomass and mean chl $a+$ phaeopigments for 1993 and 1994 showed that pigments explained ca $50 \%$ of biomass variation in the area (Fig. 4). Abundance of the non-polychaete fraction was positively correlated to all 3 pigment measures $(p<0.01)$ but not with any other of the variables (Table 4). Total biomass varied by a factor of more than 10 within the area, and abundance excluding polychaetes by a factor of more than 50 , with lowest values in the south and the highest ones in the sediment chlorophyll maximum and the northern part of the area (Figs. 5 \& 6). Similar to chl $a$, biomass and abundance showed a tendency toward SW-NE oriented peak values (Figs. $5 \& 6$ ).

\section{Macrofaunal structure}

Changes in macrofaunal structure were assessed by examining the distribution of abundance and biomass of higher taxonomic groups, as well as individual dominating species and feeding categories. Biomasses of echinoderms and polychaetes, which constituted a major part of total biomass (Fig. 5), were positively correlated with chl $a$ and with phaeopigments (Table 3 ). Abundances of echinoderms and bivalves showed similar relations with these 2 pigments (Table 4). Other significant positive correlations between taxonomical 
Table 2. Correlation matrix using Spearman's $r$ between sediment organic matter (OM) variables, sediment water content and water depth in June 1994. Chl $a=c h l a$, Phae = phaeopigments, $C P=C h l a+$ phaeopigments, PON = particulate organic nitrogen, POC = particulate organic carbon, $\mathrm{CN}=\mathrm{POC} / \mathrm{PON}$ ratio, $\mathrm{BSi}=$ biogenic silica, $\mathrm{WC}=$ water content. ${ }^{\circ} \mathrm{r}_{0.0 .5}=0.335, \cdots \mathrm{r}_{0.01}=0.430, \mathrm{n}=33$

\begin{tabular}{|c|c|c|c|c|c|c|c|c|c|}
\hline & Chl a & Phae & $\mathrm{CP}$ & PON & $\mathrm{POC}$ & $\mathrm{CN}$ & BSi & WC & Depth \\
\hline Chl a & 1.000 & $0.625 \cdots$ & - & 0.244 & -0.097 & $-0.440^{\circ}$ & 0.216 & -0.088 & 0.252 \\
\hline Phae & & 1.000 & - & -0.082 & -0.152 & -0.099 & 0.200 & -0.211 & $0.694^{*}$ \\
\hline $\mathrm{CP}$ & & & 1.000 & 0.117 & -0.136 & -0.324 & 0.230 & -0.189 & $0.531^{\cdots}$ \\
\hline $\mathrm{PON}$ & & & & 1.000 & $0.602 \cdots$ & - & 0.207 & $0.529 \cdots$ & $-0.358^{\circ}$ \\
\hline $\mathrm{POC}$ & & & & & 1.000 & - & 0.270 & $0.706^{\cdots}$ & -0.159 \\
\hline$C N$ & & & & & & 1.000 & 0.125 & 0.232 & 0.156 \\
\hline $\mathrm{BSi}$ & & & & & & & 1.000 & 0.037 & 0.059 \\
\hline WC & & & & & & & & 1.000 & -0.219 \\
\hline Depth & & & & & & & & & 1.000 \\
\hline
\end{tabular}

Table 3. Correlation matrix using Spearman's $\mathrm{r}$ between sediment OM variables, sediment water content and water depth and benthic macrofaunal biomass (AFDW) in June 1994. ${ }^{\circ} r_{005}=0.335,{ }^{\prime} r_{0.01}=0.430, n=33$. For abbreviations see Table 2

\begin{tabular}{|c|c|c|c|c|c|c|c|c|c|}
\hline & Chla & Phae & $\mathrm{CP}$ & PON & POC & $\mathrm{CN}$ & BSi & WC & Depth \\
\hline Total & $0.346^{\circ}$ & $0.499^{\circ}$ & $0.501^{\cdots}$ & 0.012 & -0.233 & -0.262 & -0.289 & -0.228 & $0.451^{\cdots}$ \\
\hline Polychaeta & $0.377^{\circ}$ & $0.497^{*}$ & $0.499 \cdots$ & 0.022 & -0.270 & -0.295 & -0.120 & $-0.357^{\circ}$ & $0.366^{\circ}$ \\
\hline Echinodermata & $0.450 \cdots$ & $0.609 \cdots$ & $0.619^{\circ}$ & 0.046 & -0.063 & -0.083 & -0.043 & -0.191 & $0.601 \cdots$ \\
\hline Crustacea & -0.119 & -0.195 & -0.217 & -0.158 & -0.248 & 0.013 & -0.189 & -0.168 & -0.129 \\
\hline Bivalvia & -0.031 & 0.088 & -0.032 & -0.166 & $-0.407^{\circ}$ & -0.108 & $-0.383^{*}$ & -0.107 & 0.104 \\
\hline Gastropoda & 0.100 & -0.130 & -0.015 & 0.054 & -0.077 & -0.268 & $-0.502^{*}$ & -0.079 & $-0.407^{\circ}$ \\
\hline Amphiura filiformis & 0.268 & $0.480^{\cdots}$ & $0.436^{\cdots}$ & 0.020 & -0.190 & -0.071 & -0.130 & -0.189 & $0.417^{\circ}$ \\
\hline $\begin{array}{l}\text { Echinodermata } \\
\text { excl. A filiformis }\end{array}$ & $0.423^{\circ}$ & $0.552 \cdots$ & $0.558 \cdots$ & -0.031 & 0.036 & -0.047 & 0.004 & -0.070 & $0.629 \cdot \cdot$ \\
\hline
\end{tabular}

Table 4. Correlation matrix using Spearman's $r$ between sediment OM variables and benthic macrofaunal abundance in June 1994. ${ }^{*} r_{0.05}=0.335,{ }^{*} r_{001}=0.430, n=33$. For further information see Table 2

\begin{tabular}{|c|c|c|c|c|c|c|c|c|c|}
\hline & Chl a & Phae & $\mathrm{CP}$ & PON & $\mathrm{POC}$ & $\mathrm{CN}$ & $\mathrm{BSi}$ & WC & Depth \\
\hline Total excl. Polychaeta & $0.453^{\cdots}$ & $0.541^{\cdots}$ & $0.560^{\circ}$ & 0.296 & -0.028 & -0.260 & 0.055 & -0.139 & 0.240 \\
\hline Echinodermata & $0.358^{\circ}$ & $0.423^{\circ}$ & $0.471^{\cdots}$ & 0.188 & -0.221 & -0.253 & -0.003 & -0.205 & 0.262 \\
\hline Crustacea & -0.054 & 0.264 & 0.130 & -0.146 & -0.003 & 0.316 & $0.345^{\circ}$ & -0.028 & $0.468^{\cdots}$ \\
\hline Bivalvia & $0.501^{\cdots}$ & $0.573 \cdots$ & $0.589 \cdots$ & 0.299 & -0.043 & $-0.339^{\circ}$ & 0.004 & -0.153 & 0.288 \\
\hline Gastropoda & 0.165 & -0.124 & -0.004 & $0.371^{\bullet}$ & 0.176 & -0.102 & 0.006 & 0.331 & $-0.585^{\cdots}$ \\
\hline Remaining taxa & 0.281 & 0.291 & $0.349^{\circ}$ & 0.111 & -0.092 & -0.103 & 0.249 & -0.049 & 0.298 \\
\hline Amphiura filiformis & $0.347^{\circ}$ & $0.418^{\circ}$ & $0.462^{\cdots}$ & 0.172 & -0.224 & -0.236 & -0.029 & -0.209 & 0.245 \\
\hline Mysella bidentata & $0.522 \cdots$ & $0.479^{\cdots}$ & $0.546^{\cdots}$ & $0.378^{\circ}$ & 0.036 & $-0.367^{\circ}$ & -0.028 & -0.061 & 0.190 \\
\hline Onoba vitrea & 0.136 & -0.166 & -0.056 & $0.373^{\circ}$ & 0.198 & -0.196 & -0.008 & $0.378^{\circ}$ & $-0.527^{\cdots}$ \\
\hline M. bidentata/A. filiformis & $0.442^{\cdots}$ & 0.316 & $0.355^{\circ}$ & 0.315 & 0.233 & -0.296 & -0.052 & 0.128 & 0.089 \\
\hline Deep feed. Mollusca & $0.536^{\cdots}$ & $0.392^{\circ}$ & $0.500^{\cdots}$ & $0.460^{\cdots}$ & 0.149 & $-0.382^{\circ}$ & -0.054 & 0.041 & 0.072 \\
\hline Surface feed. Mollusca & -0.001 & 0.316 & 0.173 & -0.288 & -0.277 & 0.187 & 0.045 & $-0.400^{\circ}$ & 0.119 \\
\hline
\end{tabular}

faunal groups and independent $O M$ variables were the ones between gastropod abundance and PON $(\mathrm{p}<$ 0.05 ) and between crustacean abundance and BSi $(\mathrm{p}<$ $0.05)$. Bivalve abundance correlated negatively with $\mathrm{C} / \mathrm{N}$ ratio $(\mathrm{p}<0.05)$

A significant fraction (Figs. $5 \& 6$ ) of increased echinoderm abundance and biomass was due to the burrow- ing ophiuroid Amphiura filiformis, a passive suspension feeder, which reached a maximum density of $>3000$ ind $\mathrm{m}^{-2}$ in the northern part of the area (Fig. 6) Biomass of this species correlated significantly positively with phaeopigments and chl $a+$ phaeopigments $(\mathrm{p}<0.01)$ and abundance showed a similar correlation with all 3 pigment measures $(p<0.05$ at least; Tables 3 

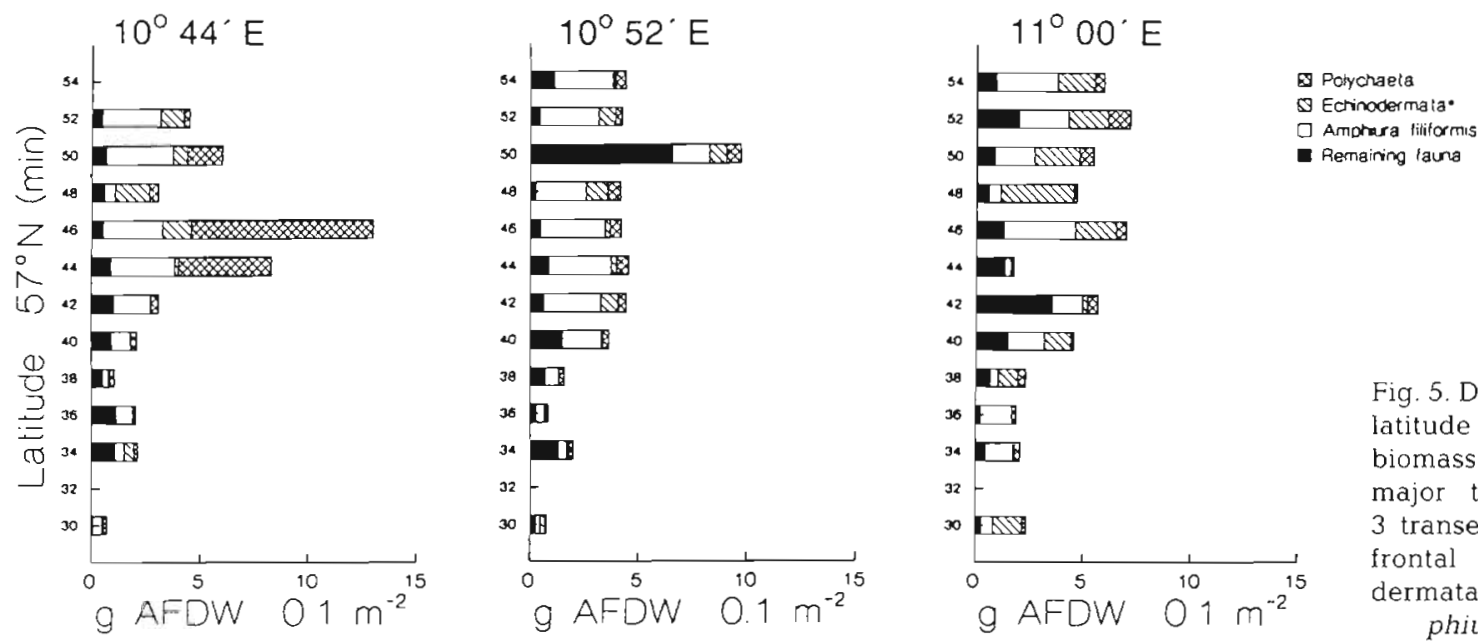

Fig. 5. Distributions with latitude of macrobenthic biomass partitioned into major taxa along the 3 transects through the frontal area. Echinodermata excluding Amphiura filiformis
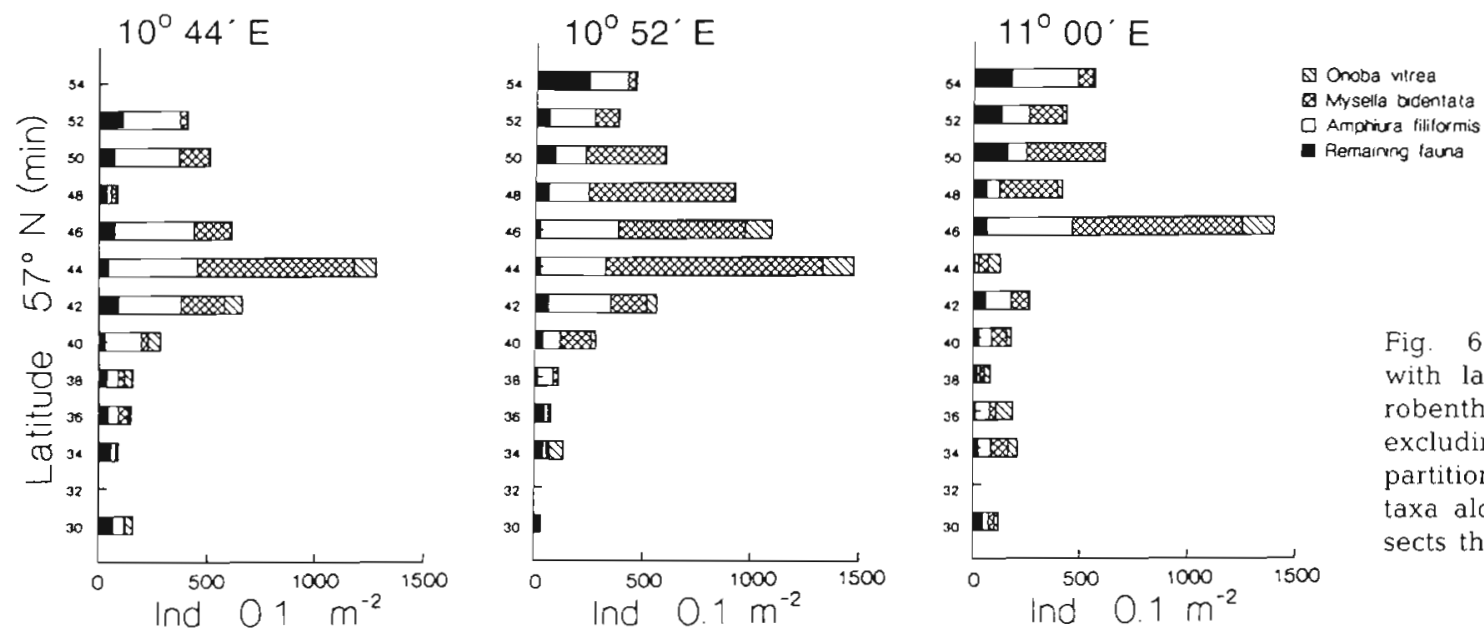

Mysella badentala

Aprivura filitormis

rom

14

D

40 ER

Distributions robenthos abundance excluding Polychaeta partitioned into major taxa along the 3 transects through the frontal area

\& 4). A major part of non-polychaete abundance, $>50 \%$, in the enriched area was due to the bivalve Mysella bidentata, which also correlated positively with chl $a$ and with phaeopigments. This species lives as a commensal in the burrows of $A$. filiformis (Ockelmann \& Muus 1978) and this fact is supported by the present data in that high density of $M$. bidentata never occurs when $A$. filiformis density is low (Fig. 6). The highest density, up to 10000 ind. $\mathrm{m}^{-2}$ of $\mathrm{M}$. bidentata, occurred in a restricted, SW-NE oriented zone in the middle of the area (Fig. 6). A. filiformis burrows in the enriched area contained on average $5 \mathrm{M}$. bidentata per burrow whereas the lowest number, $<1$ ind. per burrow, occurred in the southern and northern ends of the area. The number of $M$. bidentata per $A$. filiformis burrow correlated highly and positively with chl $a$ in the sediment (Table 4). A similar distribution as $A$. filiformis was shown by the echinoids which contribute significantly to biomass. These species also harbor commensalistic bivalves in their burrows, Montacuta tenella together with Brissopsis lyrifera (Ockelmann 1965) and Montacuta ferruginosa together with Echinocardium cordatum (Gage 1966), but numbers of these species were low. In addition, the deep-dwelling gastropod species Onoba vitrea (Josefson unpubl.) was also abundant in the enriched zone (Fig. 6).

Categorizing the numerically dominating group, Mollusca, into subsurface dwellers/feeders and those which dwell close to, or in, the sediment-water interface reveals a clear difference in spatial distribution (Fig. 7). While surface dwellers do not show any clear trend, the subsurface dwellers show a distinct unimodal pattern with a peak in the northern half of the area that progressively moves northward with increasing longitude. Correlation analysis shows significant positive correlation with chl a and with phaeopigments as well as PON for subsurface dwellers, whereas surface dwellers did not correlate significantly with these sediment variables (Table 4). 

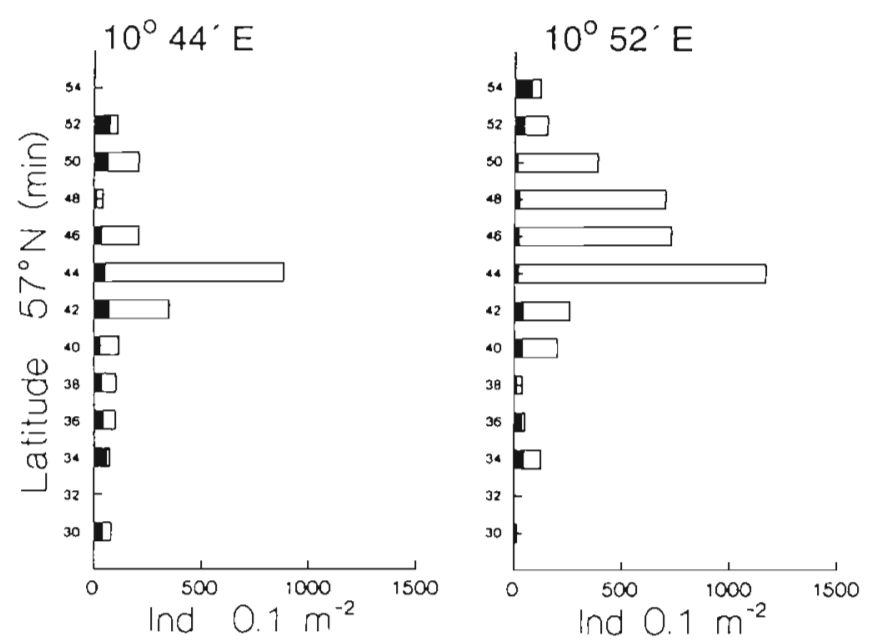

\section{Chlorophyll content in Amphiura filiformis}

The highest values of chl a in Amphiura filiformis individuals occurred in the northern part of the area and showed a SW-NE orientation (Fig. 8). The content of phaeopigments showed a similar pattern as chl $a_{\text {, }}$ and the ratio between chl $a$ and chl $a+$ phaeopigments varied mostly between 0.10 and 0.20 . The ratios in $A$. filiformis are considerably lower than the ones in the ambient surface sediment (Fig. 4) and are comparable to ratios in copepod faeces (Shuman \& Lorenzen 1975. Welschmeyer \& Lorenzen 1985) and in sediment trap material $(0.023$ to 0.155$)$, at similar depths, from various marine environments (Welschmeyer \& Lorenzen 1985).

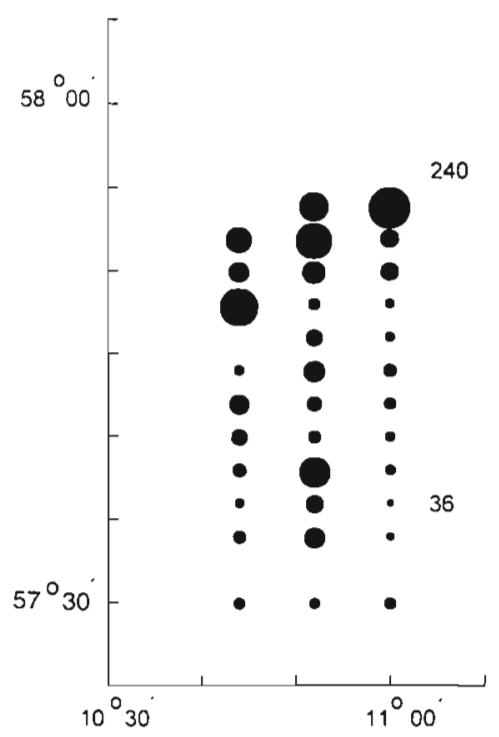

Fig. 8. Bubble plot showing spatial distribution of chl a content in Amphiura filiformis ( $\mu \mathrm{g} \mathrm{g} \mathrm{AFDW}{ }^{-1}$ ). For further information see Fig. 2

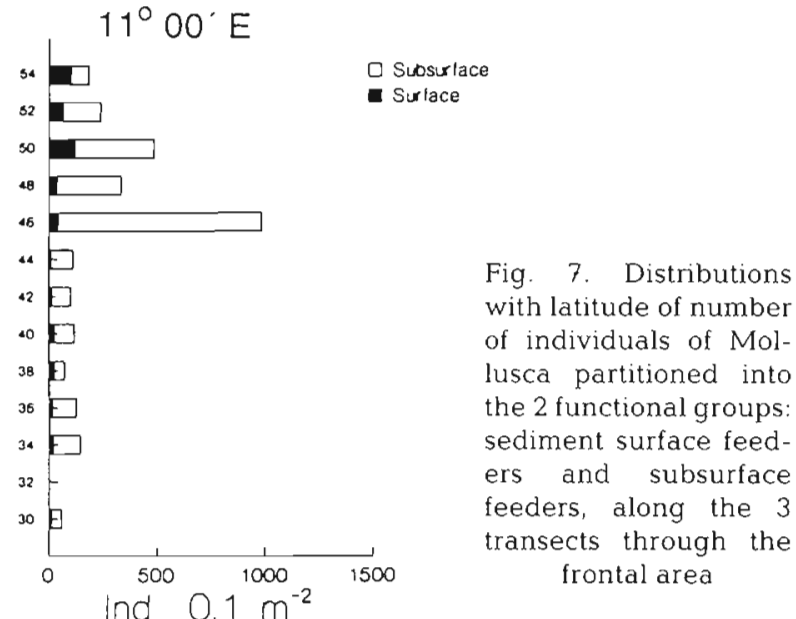

\section{DISCUSSION}

\section{Influence of the pelagic front}

Our results show that there are distinct spatial patterns of benthic biomass, abundance, chl a and phaeopigment concentrations in the area. An enriched benthic zone with high values of these variables occurs within the northern part of this area. The concentrations of chl a and phaeopigments in the sediment are elevated, and so are chl a/chl a + phaeopigments ratios, despite the presence of a very high benthos standing stock, which is likely to contribute to mineralization of the organic matter. This is a strong indication of increased input of labile OM to the bottom in that area. Furthermore, the orientation of high values of chl $a$ in the sediment (Fig. 2) and in Amphiura filiformis (Fig. 8), and of abundance (Fig. 6), in particular of subsurface feeding molluscs (Fig. 7), is approximately the same as the average orientation of the pelagic front (Fig. 1), which would be expected if there was a direct causal relation between them.

A highly conservative estimate of the strength of pelagic-benthic coupling in the enriched benthic zone may be assessed indirectly by combining the density estimates of Amphiura filiformis and literature data on production and metabolic demand. Using a production/biomass ratio of $0.46 \mathrm{yr}^{-1}$ (Sköld et al. 1994) measured on a population with similar growth characteristics as populations in the investigation area (Josefson 1995) and assuming a growth efficiency of $7 \%$ (Loo et al. 1996), the metabolic demand of Amphiura filiformis alone in the high input area (3000 ind. $\mathrm{m}^{-2}$ ) is of the same order of magnitude (140 $\mathrm{g} \mathrm{C} \mathrm{m}^{-2} \mathrm{yr}^{-1}$ ) as primary production in the area $\left(190 \mathrm{~g} \mathrm{C} \mathrm{m}^{-2} \mathrm{yr}^{-1}\right.$; Heilmann et al. 1994).

These results are in accordance with the view of strong pelagic-benthic coupling in parts of the actual 
area, which is most easily explained by high sedimentation of primary production in the frontal area. Although the coupling in the northernmost part is probably weakened by water depth, indicated by the increased proportion of phaeopigments, there are positive correlations with depth for both chl a + phaeopigments (Table 2) and biomass (Table 3). From considerations of degradation during sedimentation through the water column one would expect a negative relation with depth (e.g. Suess 1980), and therefore these results suggest substantial input of algal matter also to the deeper bottoms in the northern part of the study area. High input of OM to the bottom in the northern part of the area is also supported by a study on mineralization by Jørgensen et al. (1990) who found indications of a 2 - to 4 -fold higher input of carbon to the sediments at 1 site situated in the high biomass area described here in comparison with 4 sites in the southern Kattegat.

Generally, strong benthic-pelagic coupling may be expected in frontal areas because they are often characterized by high levels of 'new primary production'. New production is often attributed to large phytoplankters, especially diatoms (Cushing 1989, Kiørboe 1993), which have high sinking rates (Smetacek 1985). In the present case there are at least 2 possible reasons why benthic-pelagic coupling should be strong in the northern half of the investigation area. One is that production is increased in the front, which often occurs on the immediate stratified side of the front. The other is that the water mass north of the front is likely to provide favorable conditions for new production because it is often a mixed or deep mixed layer. The proportion of new primary production is thought to be greater in mixed areas, compared to stratified areas where more of the production is derived from regenerated nutrients within the photic zone (Cushing 1989, Kiørboe et al. 1990, Kiørboe 1993). In fact, it is known that along the periphery of the Skagerrak, on the southern side, which includes the northern part of the investigation area, nutrient rich bottom water is mixed with surface water thereby creating favorable conditions for new production (Kiørboe et al. 1990, Poulsen 1991), and dominance of large phytoplankters has been reported from the actual area (Kiørboe et al. 1990). Both these factors, water-mass characteristics and front production, will act to increase the input of primary production to the bottom in the northern half of the area. It is, however, at present not possible to distinguish between, or determine the contribution of, these 2 factors on the benthos. This is because the front changes position in the productive season. The 2 major currents, one going eastwards from the North Sea and the other the northward flowing Baltic current, generally meet close to Cape Skagen on the western side of the investigation area. After contact, both currents are deflected eastwards by the Coriolis force towards the Swedish west coast, and since the strengths of the currents vary, the variability in front position should be lowest to the west and higher to the east. The different chl a distributions in the sediment on the 3 dates (Fig. 2), as well as chl a in Amphiura filiformis (Fig. 8), may reflect this difference in front position variability. The pattern on the western transect, closest to Cape Skagen, is more or less the same on the 3 dates, whereas the easternmost transect shows a more variable distribution between dates. If this interpretation is correct, the effect of front sedimentation is spread over a larger area to the east than to the west, and is to a greater extent confounded by the possible effect of water-mass characteristics of the northern water mass. If so, we expect front sedimentation effects on benthos to be more spatially restricted on the western transect than on the eastern transect. The biomass pattern in Fig. 5 gives some support to this expectation in that the narrowest (leptokurtic) distribution occurs on the western transect.

An additional factor contributing to the formation of the enriched zone may be advective input. It is likely that the northern part of the area receives organic matter from other areas to a higher degree than the southern area, such as the southern part of the central and western Skagerrak and possibly also the eastern North Sea (Weering et al. 1993). The Skagerrak has been suggested to be one of the major sinks for organic carbon from large parts of the North Sea (Weering et al. 1987), and high sedimentation rates have been reported in the northern Kattegat which may be regarded as a delta formation (Fält 1982). A great part, however, of the bed load transported OM is likely to be refractory (Anton et al. 1993) and is therefore of low value as food for the benthos.

\section{Determinants of benthic biomass}

Results show that, out of several environmental variables, the 2 types of plant pigments in the sediment explained much of the variation in benthic biomass in the area. This is consistent with the idea that this macrofaunal system is fueled to a large extent by labile organic matter from the pelagic system. Biomass was significantly correlated with both chl a, phaeopigments and chl $a+$ phaeopigments. Since chl $a$ is transformed to phaeopigments when passing through the guts of grazers (Welschmeyer \& Lorenzen 1985, Hawkins et al. 1986) it cannot be excluded that high phaeopigment concentrations in sediments with abundant filter feeders, such as Amphiura filiformis, may result from biodeposition by the filter feeders (Cohen 
et al. 1984). However, the presence of high concentrations of $\mathrm{chl} a$ in the top $\mathrm{cm}$ of the sediment is less likely to be explained by biodeposition, and would rather indicate high vertical input of fresh algal matter.

The concentrations of the various measures used to trace $O M$ in the sediment are the net result of several processes, such as productivity and vertical input from the overlying water column, degradation with or without organisms, physical and/or biological mixing in the sediment, resuspension and horizontal transport. The biogeochemistry of these biomarkers and the time periods in which these processes are effective are likely to differ considerably, and it is therefore not surprising to find only weak or no correlations between the different measures. Chl $a$ is likely to have the shortest history, with half-lives ranging from 13 to $25 \mathrm{~d}$ in sediments devoid of macrofauna (Sun et al. 1991) to less than a few hours in the guts of grazers (Hawkins et al. 1986), and thereby may be the best biomarker to reflect the production and vertical sedimentation of phytoplankton. The half-life of phaeopigments may be in the order of $40 \mathrm{~d}$ (Furlong \& Carpenter 1988) and for BSi from months (Gehlen \& Raaphorst 1995) to centuries (Treguer et al. 1995). The bulk measures of POC and PON in sediments more often than not reflect refractory, or more or less humified, material which may be of little value as food for macroconsumers (e.g. Rice 1982). Consistent with other studies (Levinton \& Stewart 1988, Burford et al. 1994), POC is a particularly poor indicator of macrofaunal abundance and biomass. PON was shown to be a useful predictor of benthic biomass in Bering Sea sediments (Lomstein et al. 1989), but present results did not show the same clear relationship, although relationships with $\mathrm{C} / \mathrm{N}$ ratio had the expected slope. This illustrates the problem of using bulk measures where the composition and quality of the material is unknown. The fact that measurements of $O M$ compounds with different degrees of lability do not correlate well with each other illustrates that factors other than sedimentation are important for the distribution of OM in the area. Horizontal transport and/or differential degradation are likely examples of such factors.

Whether or not the input of diatoms to the bottom of is increased in the frontal area is not directly shown by our data. BSi concentrations were uncorrelated with most variables. However, similar to measures of labile OM, the input of BSi to the bottom is likely to be much higher in the high biomass zone than indicated by sediment concentrations. Dissolved silicate flux from the sediment is strongly and positively regulated by the activities of burrowing animals (Aller 1988). It has been shown that the efflux of dissolved silicate from a bottom populated with a similar Amphiura filiformisMysella bidentata community, but with lower density than here, was up to an order of magnitude higher as compared to sediment without macrofauna (Rutgers van der Loeff et al. 1984). Despite the very high benthos density in the enriched zone, BSi concentrations are not significantly lower than elsewhere in the investigation area, and relative to the nearby North Sea sediments (Gehlen \& Raaphorst 1993) BSi concentrations are 5 to 25 times higher in the Kattegat. This suggests a generally high input of material of diatom origin.

Our findings of chl $a$ and phaeopigments as major determinants of benthic macrofaunal biomass may be expected from some previous work. It has been postulated that there should be a strong evolutionary linkage between macrofaunal organisms and diatoms (Slobodkin \& Richman 1961). Since macrofauna have the ability to store energy, it should be well suited to utilize the unpredictable diatom pulses to the bottom. Some recent studies do indicate a coupling between diatoms and macrofaunal density (Johnson \& Wiederholm 1992), growth (Beukema \& Cadee 1991, Johnson \& Wiederholm 1992) and respiration (Fitzgerald \& Gardner 1993). Increased macrofaunal growth has been demonstrated immediately following the spring bloom sedimentation (Graf et al. 1982, Christensen \& Kanneworff 1985), which consists mainly of diatoms. Burford et al. (1994) showed significant positive relations between sediment algal pigments and macrofaunal abundance in an Australian bay, and Heip et al. (1992) showed a similar relation for biomass in the North Sea. The results add to the view that sediment bulk carbon is of little value in predicting macrofaunal standing stock.

\section{Macrofaunal structure}

Macrofaunal composition shows a differential response to the OM gradient. A major feature is the dramatic increase of the ophiuroid Amphiura fillformis and its commensal Mysella bidentata in the area with high chlorophyll concentrations in the sediment. The combination of high input of labile OM and availability of secondary bottoms in the form of irrigated burrows provide possibilities for extensive subsurface dwelling of macrofauna in the enriched zone. One factor that may contribute to faunal structural differences within the investigation area is the presence of relatively strong near-bottom currents in the northern part of the area which may provide suitable feeding conditions for passive filter feeders like $A$. filiformis. We further hypothesize that the evolution of such a system as has been observed here may be mediated by space limitation at the sediment-water interface of the primary bottom. A fact that may support this is that the number of coinhabitants ( $M$. 
bidentata) per burrow is increased in the chlorophyll maximum zone and is in fact highly correlated with chl $a$, whereas the number of $A$. filiformis burrows seems to have reached an upper limit. Space limitation of $A$. filiformis at the high densities encountered in the investigation area here $\left(>3000\right.$ ind. $\left.\mathrm{m}^{-2}\right)$ has been suggested previously (Josefson 1995, Rosenberg 1995). At least the differential distribution of $\mathrm{A}$. filiformis and $M$. bidentata suggest that different factors limit the numbers of both species. In accordance with this hypothesis is also the fact that surface deposit feeding molluscs, and most crustaceans (amphipods and cumaceans), most of which may be dependent on sediment surface for feeding, do not respond to the increased $O M$ input, while subsurface feeding molluscs increase dramatically in the high pigment area. If this interpretation is correct, the benthic response in terms of structure is not only a matter of differences in feeding preferences, but also related to differential utilisation of limited space at the sediment-water interface.

A functional implication of the echinoderm-bivalve 'system' is that a substantial part of OM is transported and processed deep, typically 3 to $7 \mathrm{~cm}$, into the sediment. In amphiurids as well as echinoids the OM is trapped and transported externally on the body down to the mouth which is situated in the deepest part of the burrow. This means that fresh OM may be available for co-inhabiting organisms in the burrow. It is known that Mysella bidentata may ingest diatoms in the field (Ockelmann \& Muus 1978). The results on chlorophyll content in Amphiura filiformis clearly indicate that this species does ingest algal material and most likely that transformation/ digestion of this material takes place within them. Thus, subsurface processing of fresh OM, at least by macrofauna, should be greater in the enriched area.

Another implication is that mineralization of $O M$ is likely to be considerably increased in the high input area because of the increase in the bottom surface area due to the irrigated burrows created by Amphiura filiformis. Using the data given by Ockelmann \& Muus (1978) on burrow characteristics and combined with our density estimates of adult $A$. filiformis (disc diameter $>5 \mathrm{~mm}$ ), the increase in bottom area where at least oxic processes occur is up to an order of magnitude (10 times) higher in the high input area as compared to the southern part of the area. The consequences of this tremendous change in the 3-dimensional mosaic of the bottom for the flux of nutrients back to the pelagic system is difficult to predict (Aller 1988), but it seems safe to assume that the overall rates of mineralization are significantly increased (Jorgensen et al 1990). Whether such areas are sources or sinks for nutrients would be an important topic for future research.
Acknowledgements. Thanks to Jorgen N. Jensen and Flemming Mohlenberg for field assistance, to Anja Friis-Christensen, Anita Piper Jørgensen, Grete Dinesen, Lasse Gudmundson, and Birgit Søborg for technical assistance. The paper benefited from the constructive comments of 4 anonymous referees.

\section{LITERATURE CITED}

Aller RC (1988) Benthic fauna and biogeochemical processes in marine sediments: The role of burrow structures. In: Blackburn TH, Sorensen J (eds) Nitrogen cycling in coastal marine environments. SCOPE, John Wiley \& Sons Ltd, London, p 301-338

Anton KK, Liebezeit G, Rudolph C, Wirth H (1993) Origin, distribution and accumulation of organic carbon in the Skagerrak. Mar Geol 111:287-297

Barry JP, Dayton PK (1991) Physical heterogeneity and the organization of marine communities. In: Kolasa J, Pickett STA (eds) Ecological heterogeneity. Ecological studies Vol 86. Springer-Verlag, New York, p 270-320

Beukema JJ, Cadee GC (1991) Growth rates of the bivalve Macoma balthica in the Wadden Sea during a period of eutrophication: relationships with concentrations of pelagic diatoms and flagellates. Mar Ecol Prog Ser 68: 249-256

Burford MA, Long BG, Rothlisberg PC (1994) Sedimentary pigments and organic carbon in relation to microalgal and benthic faunal abundance in the Gulf of Carpentaria. Mar Ecol Prog Ser 103:111-117

Christensen H, Kanneworff E (1985) Sedimenting phytoplankton as major food source for suspension and deposit feeders in the Øresund. Ophelia 24:223-244

Cleveland WS (1979) Robust locally weighted regression and smoothing scatterplots. J Am Statist Ass 74:829-836

Cohen RRH, Dresler PV, Phillips EJP, Cory RL (1984) The effects of the Asiatic clam, Corbicula fluminea, on phytoplankton of the Potomac River, Maryland. Limnol Oceanogr 29:170-180

Conley DJ (1988) Biogenic silica as an estimate of siliceous microfossil abundance in Great Lakes sediments. Biogeochemistry 6:161-179

Cramer A (1990) Seasonal variation in benthic metabolic activity in a frontal system in the North Sea. In: Barnes $M$, Gibson RN (eds) Trophic relationships in the marine environment. Aberdeen University Press, Aberdeen, p 54-76

Creutzberg $F$ (1985) A persistent chlorophyll a maximum coinciding with an enriched benthic zone. In: Gibbs PE (ed) Proc 19th Eur Mar Biol Symp. Cambridge University Press, Cambridge, p 97-108

Creutzberg F, Wapenaar P, Duineveld G, Lopez NL (1984) Distribution and density of the benthic fauna in the southern North Sea in relation to bottom characteristics and hydrographic conditions. Rapp PV Réun Cons Int Explor Mer 183:101-110

Cushing DH (1989) A difference in structure between ecosystems in strongly stratified waters and in those that are only weakly stratified. J Plankton Res 11:1-13

Daemen EAMJ (1986) Comparison of methods for the determination of chlorophyll in estuarine sediments. Neth J Sea Res 20:21-28

DeMaster DJ (1981) The supply and accumulation of silica in the marine environment. Geochim Cosmochim Acta 45: $1715-1732$

Duineveld GCA, Kunitzer A, Heyman RP (1987) Amphiura filiformis (Ophiuroidea: Echinodermata) in the North Sea. 
Distribution, present and former abundance and size composition. Neth J Sea Res 21:317-329

Fält LM (1982) Late quaternary sea-floor deposits off the Swedish west coast. Dept Geology, University of Gothenburg, Gothenburg, Publ A 37:1-259

Fitzgerald SA, Gardner WS (1993) An algal carbon budget for pelagic-benthic coupling in Lake Michigan. Limnol Oceanogr 38:547-560

Furlong ET, Carpenter R (1988) Pigment preservation and remineralization in oxic coastal marine sediments. Geochim Cosmochim Acta 52:87-99

Gage J (1966) The life-histories of the bivalves Montacuta substriata and $M$. ferruginosa 'commensals' with spatangoids. J Mar Biol Ass UK 46:499-511

Gehlen M, Raaphorst W van (1993) Early diagenesis of silica in sandy North Sea sediments: quantification of the solid phase. Mar Chem 42:71-83

Gehlen M, Raaphorst W van (1995) Spatial and temporal variability of benthic silica fluxes in the south-eastern North Sea. Cont Shelf Res 15:1675-1696

Graf G (1992) Benthic-pelagic coupling: a benthic view. Oceanogr Mar Biol Annu Rev 30:149-190

Graf G, Bengtsson W, Diesner U, Schulz R, Theede H (1982) Benthic response to sedimentation of a spring phytoplankton bloom: process and budget. Mar Biol 67:201-208

Grebmeier JM, McRoy CP (1989) Pelagic-benthic coupling on the shelf of the northern Bering and Chukchi Seas. III. Benthic food supply and carbon cycling. Mar Ecol Prog Ser 53:79-91

Hargrave BT (1973) Coupling carbon flow through some pelagic and benthic communities. J Fish Res Bd Can 30: $1317-1326$

Hawkins AJS, Bayne BL, Mantoura RFC, Llewellyn CA, Navarro E (1986) Chlorophyll degradation and absorption throughout the digestive system of the blue mussel Mytilus edulis L. J Exp Mar Biol Ecol 96:213-223

Heilmann J, Richardson K, Extebjerg G (1994) Annual distribution and activity of phytoplankton in the Skagerrak/ Kattegat frontal region. Mar Ecol Prog Ser 112:213-223

Heip C, Basford D, Craeymeersch JA, Dewarumez JM, Dørjes J, Wilde P de, Duineveld G, Eleftheriou A, Herman PMJ, Niermann U, Kingston P, Kunitzer A, Rachor E, Rumohr H, Soetaert K, Soltwedel T (1992) Trends in biomass, density and diversity of North Sea macrofauna. ICES J Mar Sci 49 : $13-22$

Iverson RL, Coachman LK, Cooney RT, English TS, Goering JJ, Hunt GL, Macauley MC, MacRoy CP, Reeburg WS, Whitledge TE (1979) Ecological significance of fronts in the southeastern Bering Sea. In: Livingstone RJ (ed) Ecological processes in coastal and marine systems. Plenum, New York, p 437-466

Jakobsen F, Attebjerg G, Agger CT, Højerslev NK, Holt N, Heilmann J, Richardson K (1994) Hydrografisk og biologisk beskrivelse af Skagerrak-fronten. Havforskning fra Miljøstyrelsen, Miljøministeriet, Miljøstyrelsen (in Danish with English summary)

Jespersen AM, Christoffersen K (1987) Measurements of chl a from phytoplankton using ethanol as extraction solvent. Arch Hydrobiol 109:445-454

Johnson RK, Wiederholm T (1992) Pelagic-benthic couplingthe importance of diatom interannual variability for population oscillations of Monoporeia affinis. Limnol Oceanogr $37: 1596-1607$

Jørgensen BB, Bang M, Blackburn TH (1990) Anaerobic mineralization in marine sediments from the Baltic Sea-North Sea transition. Mar Ecol Prog Ser 59:39-54

Josefson AB (1995) Large-scale estimate of somatic growth in
Amphiura filiformis (Echinodermata: Ophiuroidea). Mar Biol 124:435-442

Josefson AB, Jensen JN (1992) Growth patterns of Amphiura filiformis support the hypothesis of organic enrichment in the Skagerrak-Kattegat area. Mar Biol 112:615-624

Kiorboe T (1993) Turbulence, phytoplankton cell size, and the structure of pelagic food webs. Adv Mar Biol 29:1-72

Kiorboe T, Kaas H, Kruse B, Mohlenberg F, Tiselius P, Artebjerg $G(1990)$ The structure of the pelagic food web in relation to water column structure in the Skagerrak. Mar Ecol Prog Ser 59:19-32

Levinton JS, Stewart S (1988) Effects of sediment organics, detrital input, and temperature on demography, production, and body size of a deposit feeder. Mar Ecol Prog Ser 49:259-266

Lindley JA, Williams R (1994) Relating plankton assemblages to environmental variables using instruments towed by ships-of-opportunity. Mar Ecol Prog Ser 107:245-262

Lomstein BAa, Blackburn TH, Henriksen K (1989) Aspects of nitrogen and carbon cycling in the northern Bering Shelf sediment. I. The significance of urea turnover in the mineralization of $\mathrm{NH}_{4}{ }^{+}$. Mar Ecol Prog Ser 57:237-247

Loo LO, Jonsson P, Sköld M, Karlsson Ö (1996) Passive suspension feeding in Amphiura filiformis (Echinodermata: Ophiuroidea): feeding behaviour in flume flow and potential feeding rate of field populations. Mar Ecol Prog Ser 139:143-155

Lorenzen CJ (1967) Determination of chlorophyll and phaeopigments: spectrophotometric equations. Limnol Oceanogr 12:343-346

Mantoura RFC, Llewellyn CA (1983) The rapid determination of algal chlorophyll and carotenoid pigments and their breakdown products in natural waters by reverse-phase high-performance liquid chromatography. Analyt Chim Acta 151:297-314

Ockelmann KW (1965) Redescription, distribution, biology and dimorphous sperm of Montacuta tenella Loven (Mollusca, Leptonaceaj. Ophelia 2:211-221

Ockelmann KW, Muus K (1978) The biology, ecology and behaviour of the bivalve Mysella bidentata (Montagu). Ophelia 17:1-93

Pingree RD, Holligan PM, Mardell GT (1978) The effects of vertical stability on phytoplankton distributions in the summer on the northwest European Shelf. Deep Sea Res 25:1011-1028

Poulsen O (1991) The hydrography of Skagerrak and Kattegat, The dynamics of the Skagerrak Front. Institute of Hydrodynamics and Hydraulic Engineering, Technical University of Denmark, Lyngby, Series Paper No. 54: $1-164$

Rice D (1982) The detritus nitrogen problem: new observations and perspectives from organic geochemistry. Mar Ecol Prog Ser 9:153-162

Richardson K (1985) Plankton distribution and activity in the North Sea/Skagerrak-Kattegat frontal area in April 1984. Mar Ecol Prog Ser 26:233-244

Riegman R, Malschaert H, Colijn F (1990) Primary production of phytoplankton at a frontal zone located at the northern slope of the Dogger Bank (North Sea). Mar Biol 105: $329-336$

Rodhe J (1996) On the dynamics of the large-scale circulation of the Skagerrak. J Sea Res 35:9-21

Rosenberg $R$ (1995) Benthic marine fauna structured by hydrodynamic processes and food availability. Neth J Sea Res 34:303-317

Rutgers van der Loeff MM, Anderson LG, Hall POJ, Iverfeldt $\AA$, Josefson AB, Sundby B, Westerlund SFG (1984) The 
asphyxiation technique: an approach to distinguishing between molecular diffusion and biologically mediated transport at the sediment-water interface. Limnol Oceanogr 29:675-686

Shuman FR, Lorenzen CJ (1975) Quantitative degradation of chlorophyll by a marine herbivore. Limnol Oceanogr 20 : $580-586$

Sköld M, Loo LO, Rosenberg R (1994) Production, dynamics and demography of an Amphiura filiformis population. Mar Ecol Prog Ser 103:81-90

Slobodkin LB, Richman S (1961) Calories/gm in species of animals. Nature 191:299

Smetacek V (1980) Annual cycle of sedimentation in relation to plankton ecology in western Kiel Bight. Ophelia Supp] $1: 65-76$

Smetacek VS (1985) Role of sinking in diatom life-history cycles: ecological, evolutionary and geological significance. Mar Biol 84:239-251

Sun M, Aller RC, Lee C (1991) Early diagenesis of chlorophyll-a in Long Island Sound sediments: a measure of carbon flux and particle reworking. J Mar Res 49:379-401

This article was submitted to the editor
Suess E (1980) Particulate organic carbon flux in the oceanssurface productivity and oxygen utilization. Nature 288: $260-263$

Svansson A (1975) Physical and chemical oceanography of the Skagerrak and the Kattegat. I. Open sea conditions. Fish Bd Sweden 1:1-88

Treguer $P$, Nelson DM, Bennekom AJ Van, DeMaster DJ, Leynaert A, Quequiner B (1995) The silica balance in the world ocean: a reestimate. Science 268:375-379

Tumbiolo ML, Downing JA (1994) An empirical model for the prediction of secondary production in marine benthic invertebrate populations. Mar Ecol Prog Ser 114:165-174

Weering TCE van, Berger GW, Kalf J (1987) Recent sediment accumulation in the Skagerrak, northeastern North Sea. Neth J Sea Res 21:177-189

Weering TCE van, Berger GW, Okkels E (1993) Sediment transport, resuspension and accumulation rates in the northeastern Skagerrak. Mar Geol 111:269-285

Welschmeyer NA, Lorenzen CJ (1985) Role of herbivory in controlling phytoplankton abundance: annual pigment budget for a temperate marine fjord. Mar Biol 90:75-86

Manuscript first received: August 16, 1996

Revised version accepted: December 23, 1996 